\title{
Analysis of Factors Associated with Birth Weight
}

\author{
Shinya Matsuda \\ Department of Human Ecology, School of Medicine, University \\ of Occupational and Environmental Health, Kitakyushu
}

\section{INTRODUCTION}

It has been suggested that there is a close relationship between birth weight distribution and socio-economic development ${ }^{1 \sim 4}$. It seems that the better the socio-economic environment, the heavier the mean birth weight in a given community. The Sigtuna workshop ${ }^{1)}$ concluded that birth weight distribution can be a useful indicator of the overall health condition of a particular community, especially in developing countries. As a socio-economic indicator, birth weight distribution has the following merits:

1) It is easier to measure and to obtain than other social indicators like Gross National Product (GNP).

2) It is a positive health index which is appropriate for planning and evaluating social development ${ }^{11}$.

3) The number of births is usually larger than the number of deaths in a given community ; therefore, the characteristics describing the birth weight distribution are less affected by the size of the population than those of death.

4) It provides an ideal follow-up system with the monitoring of growth and development of infants because low birth weight is an important risk factor in infant mortality ${ }^{5,6)}$.

In order to formulate a strategy for community health development using the birth weight distribution as a yardstick, it is necessary to analyze factors associated with birth weight. Factors with well-established impacts on birth weight include infant $\operatorname{sex}^{7 \sim 11)}$, racial/ethnic origin ${ }^{8,9,11)}$, maternal height $^{7,11 \sim 13)}$, paternal height ${ }^{14)}$, maternal birth weight ${ }^{10)}$, parity ${ }^{7,11}$, maternal weight ${ }^{7,10,13)}$, gestational weight gain $^{8,10,13,15,16)}$, gestational caloric intake ${ }^{15,17 \sim 19)}$, cigarette smoking ${ }^{10,11,16,20)}$, and so on. It should be noted, however, that prevalences of these factors and the magnitude of each factor may be different among populations.

It was reported that the secular change of the mean birth weight (MBW) of Okinawa was different from that of Japan as a whole ${ }^{21,22)}$. The MBW of Okinawa has been lower than that of all Japan, but the increase rate of the MBW in Okinawa has been larger. The MBW in Japan specified by the sex of infants increased from 1969 to 1976 with maximums in both males $(3,254 \mathrm{~g})$ and females $(3,172 \mathrm{~g})$ in 1976 and then decreased, while that of Okinawa increased until 1979 with maximums in both males $(3,220 \mathrm{~g})$ and females (3,137 g) and then decreased. Kahyo et al. ${ }^{23,24)}$ studied the characteristics of the MBW in Okinawa using birth records of two obstetric facilities in Okinawa, and concluded that this high increase rate of the MBW was due to the marked improvement of the socio-economical environment in Okinawa after the Second World War.

The purpose of this study is to evaluate factors associated with birth weight in Okinawa by means of multiple regression analyses.

\section{Materials AND Methods}

Data were collected at a private obstetric facility in the city of Naha, Okinawa, Japan, from 1978 to 1987. There were 4,426 deliveries at this facility in 10 years. Information on mothers (age, height, pre-pregnancy weight, the final weight, history of prior prematurity, prior induced abortion and spontaneous abortion), infants (sex, gestational weeks, malformation, singleton or not, stillbirth or not, and birth weight), and delivery situations was obtained from the medical records after deliveries.

Of the 4,426 infants, 4,321 were live singletons with data available to calculate the mean birth weight, 
and 3,000 (male : 1,500, female : 1,500; there was no selection of cases) had enough information for multiple regression analyses of birth weight and gestational weeks. Factors examined for their effects on birth weight or gestational weeks in the regression model were as follows :

1) For birth weight - maternal age, pre-pregnancy body mass index (BMI) of the mother, gestational weight gain of the mother, maternal height, prior prematurity, prior induced abortion, prior spontaneous abortion, parity, gestational weeks, sex of infant.

2) For gestational weeks - maternal age, pre-pregnant BMI of mother, maternal height, prior prematurity, prior induced abortion, prior spontaneous abortion, parity, and sex of infant.

Exclusion: In this investigation we excluded multiple births and stillbirths, live-born singletons with unknown birth weight, unknown gestational weeks, malformations and Caesarean operations, and cases without any data necessary for analysis.

Remarks on some variables:

1) Maternal height: This was measured by nurses or midwives at the first visit to this facility.

2) Body Mass Index: The Quetelet index ${ }^{25}$ was used in our analyses to examine the effects of the pre-pregnancy nutritional condition. It is well known that there is a high correlation between weight and height, and that both of them have an effect on birth weight ${ }^{7,10 \sim 13)}$. For this reason BMI was used in analyses to control the confounding effect of maternal height. The formula used is as follows :

$\mathrm{BMI}=\left((\right.$ Body weight in kilograms $\left.) /(\text { Height in meters })^{2}\right) \times 10^{4}$

Pre-pregnancy weights were reported by mothers in personal interviews.

3) Gestational weight gain: This was calculated by subtracting the pre-pregnancy weight from the final weight.

4) Gestational weeks at delivery: This was computed from the date of the last menstrual period as reported by the mother, and described as completed weeks.

5) Birth weight: This was measured to the nearest $10 \mathrm{~g}$ by nurses or midwives soon after the delivery using a boby-scale.

Statistical approach: The SPSSx package was used for all of the analyses ${ }^{26)}$. As a multiple regression analysis, the stepwise method, where the probability of $\mathrm{F}$-to-enter is equal to 0.05 , and the probability of F-to-remove is equal to 0.10 , was used.

\section{RESULTS}

Table 1 shows descriptive statistics of all variables used in the multiple regression model. The mean and standard deviation (S.D.) of the birth weight of infants in this study were $3,213.9 \mathrm{~g}$ and $432.5 \mathrm{~g}$, respectively, which were almost the same as those of 4,321 infants with known birth weight in this facility (Mean : 3,210.6 g, S.D. : $438.7 \mathrm{~g}$ ). The MBWs of males and females in this study were 3,255.2 g and 3,172. $7 \mathrm{~g}$, respectively, which were slightly heavier than those of Japan as a whole (male : 3,200-3,240 $\mathrm{g}$, female : $3,120-3,160 \mathrm{~g} ; 1978-87$ ) and those of Okinawa prefecture (male : 3,160-3,210 g, female : 3,080-3, $130 \mathrm{~g} ; 1978-87)^{27)}$. The percentages of male and female infants with LBW were $5.1 \%$ and $4.2 \%$, respectively, which were higher for males but lower for females than those of all Japan (male: $4.1-4.6 \%$, female : $4.8-5.5 \%$; 1978-87) while both of them were lower than those of Okinawa (male : $5.4-6.6 \%$, female : $5.9-6.6 \% ; 1978-87)^{27}$. The mean age of women in this study was 27.3 , which was younger than that of all Japan $(28.0-28.6 ; 1978-87)^{27)}$.

Table 2 shows the result of the multiple regression analysis of birth weight. Nine variables were included in the equation as factors with significant effects. Among them, gestational weeks, BMI, gestational weight gain, parity, maternal height, and maternal age had positive effects on birth weight, whereas prior prematurity and prior spontaneous abortion had negative effects. Male infants had heavier birth weights than females. According to the squared R, primary correlate was gestational weeks, which alone accounted for $18 \%$ of the variation in birth weight; the remaining factors together accounted for about $14 \%$. The magnitude of effect of each factor could be estimated from the regression coefficient.

Table 3 shows changes of the relationship between birth weight and independent variables for three 
Table 1 Variables analyzed by multiple regression models $(N=3000)$.

\begin{tabular}{lrc}
\hline \multicolumn{1}{c}{ Variables $^{\text {a) }}$} & Mean & S.D. \\
\hline BW (g) & 3213.9 & 432.5 \\
GPR (weeks) & 39.2 & 1.7 \\
AGE & 27.3 & 4.5 \\
MHT (cm) & 153.6 & 4.5 \\
BMI & 20.9 & 2.6 \\
GWG (Kg) & 12.3 & 3.9 \\
PAR ${ }^{\text {b) }}$ & 1.04 & 1.06 \\
PIA & 0.34 & 0.73 \\
PSA & 0.17 & 0.47 \\
PMT & 0.04 & 0.22 \\
SEX & Male : Female $=1.0: 1.0$ \\
\hline
\end{tabular}

a) BW: Birth weight; GPR: Gestational period; AGE : Maternal age; MHT: Maternal height; BMI : Body Mass Index; GWG : Gestational weight gain; PAR: Parity; PIA : Prior induced abortion; PSA : Prior spontaneous abortion; PMT : Prior prematurity SEX : Infant sex b) Parity: Number of previous deliveries

Table 2 Factors associated with birth weight analyzed by a multiple regression model $(N=3000$, stepwise method $^{\mathrm{a})}$ ).

\begin{tabular}{|c|c|c|c|c|c|}
\hline Step & $\mathrm{VAR}^{\mathrm{b})}$ & Cumulativ & squared $\mathrm{R}$ & Beta $^{c)}$ & Regression coefficient \\
\hline 1 & GPR & .1812 & & .4257 & $108.6 \mathrm{~g} /$ week \\
\hline 2 & BMI & .2202 & $(.0390)$ & .1976 & $32.8 \mathrm{~g} / \mathrm{BMI}$ \\
\hline 3 & GWG & .2685 & $(.0483)$ & .2259 & $25.6 \mathrm{~g} / \mathrm{Kg}$ \\
\hline 4 & PAR $^{\mathrm{d})}$ & .2927 & $(.0242)$ & .1598 & $61.0 \mathrm{~g}$ \\
\hline 5 & $\mathrm{SEX}^{\mathrm{e})}$ & .3111 & $(.0184)$ & -.1365 & $-115.2 \mathrm{~g}$ \\
\hline 6 & MHT & .3138 & $(.0027)$ & .0864 & $8.8 \mathrm{~g} / \mathrm{cm}$ \\
\hline 7 & AGE & .3208 & $(.0070)$ & .0591 & $5.9 \mathrm{~g} /$ year \\
\hline 8 & PMT & .3232 & $(.0024)$ & -.0495 & $-92.2 \mathrm{~g} / \mathrm{birth}$ \\
\hline 9 & PSA & .3243 & $(.0011)$ & -.0337 & $-32.0 \mathrm{~g} / \mathrm{birth}$ \\
\hline
\end{tabular}

a) Probability of F-to-enter $=0.05$; Probability of F-to-remove $=0.10$ b) VAR: Abbreviations of variables are the same as those in Table 1 c) Standardized regression coefficient; d) primiparae $=0$, multiparae $=1$ e) male $=0$, female $=1 \quad(\quad$ ) Increment of squared $R$ with each factor

different gestational weeks. It is well known that the relationship between birth weight and gestational weeks is not linear. According to Gruenwald ${ }^{28}$, the rate of fetal growth deviates from a straight line after 38 weeks of gestation and particularly after 40 weeks. We took account of the nonlinearity of this relationship and analyzed births with 41 or fewer gestational weeks, 40 or fewer, and 39 or fewer. It was observed that the shorter the number of gestational weeks, the larger the increment of squared Rs of gestational weeks, whereas the increments of the squared Rs of other variables were almost the same among the three equations.

Table 4 shows results of multiple regression analyses within each of two parity groups, primiparae and multiparae, where the number of prior live births was used as an independent variable instead of the 
Table 3 Factors associated with birth weight analyzed by a multiple regression model for three different gestational weeks (stepwise method $^{\mathrm{a})}$ ).

\begin{tabular}{|c|c|c|c|c|c|c|}
\hline \multirow[b]{2}{*}{ Step } & \multicolumn{2}{|c|}{ GPR $\leqq 39$ weeks } & \multicolumn{2}{|c|}{$\mathrm{GPR} \leqq 40$ weeks } & \multicolumn{2}{|c|}{$\mathrm{GPR} \leqq 41$ weeks } \\
\hline & $\mathrm{VAR}^{\mathrm{b})}$ & $\begin{array}{l}\text { Cumulative } \\
\text { squared R }\end{array}$ & VAR & $\begin{array}{l}\text { Cumulative } \\
\text { squared R }\end{array}$ & VAR & $\begin{array}{l}\text { Cumulative } \\
\text { squared R }\end{array}$ \\
\hline 1 & GPR & .2570 & GPR & .2239 & GPR & .1949 \\
\hline 2 & BMI & $.2916(.0346)$ & BMI & $.2635(.0396)$ & BMI & $.2344(.0395)$ \\
\hline 3 & GWG & $.3327(.0411)$ & GWG & $.3050(.0415)$ & GWG & $.2797(.0453)$ \\
\hline 4 & PAR & $.3540(.0213)$ & PAR & $.3259(.0209)$ & PAR & $.3020(.0223)$ \\
\hline 5 & $\mathrm{SEX}^{\mathrm{c})}$ & $.3641(.0101)$ & SEX & $.3449(.0190)$ & SEX & $.3190(.0170)$ \\
\hline 6 & MHT & $.3688(.0047)$ & MHT & $.3538(.0089)$ & MHT & $.3269(.0079)$ \\
\hline 7 & PSA & $.3705(.0017)$ & PMT & $.3553(.0015)$ & AGE & $.3287(.0018)$ \\
\hline 8 & & & & & PMT & $.3305(.0018)$ \\
\hline 9 & & & & & PSA & $.3316(.0011)$ \\
\hline
\end{tabular}

a) Probability of F-to-enter $=0.05$; Probability of F-to-remove $=0.10$ b) VAR: Variables ; Abbreviations of variables are the same as those in Table 1 c) male $=0$, female $=1 \quad(\quad)$ Increment of $R^{2}$ with each factor

Table 4 Factors associated with birth weight analyzed by multiple regression analyses within each of two parity groups (stepwise method $\left.{ }^{\mathrm{a})}\right)$.

\begin{tabular}{|c|c|c|c|c|c|c|}
\hline \multirow[b]{2}{*}{ Step } & \multicolumn{3}{|c|}{ Primiparae } & \multicolumn{3}{|c|}{ Multiparae } \\
\hline & $\mathrm{VAR}^{\mathrm{b})}$ & $\begin{array}{l}\text { Cumulative } \\
\text { squared R }\end{array}$ & $\begin{array}{l}\text { Regression } \\
\text { coefficient }\end{array}$ & VAR & $\begin{array}{l}\text { Cumulative } \\
\text { squared R }\end{array}$ & $\begin{array}{l}\text { Regression } \\
\text { coefficient }\end{array}$ \\
\hline 1 & GPR & .1863 & $100.6 \mathrm{~g} /$ week & GPR & .1976 & $114.4 \mathrm{~g} /$ week \\
\hline 2 & GWG & $.2455(.0592)$ & $26.8 \mathrm{~g} / \mathrm{Kg}$ & GWG & $.2377(.0401)$ & $25.9 \mathrm{~g} / \mathrm{Kg}$ \\
\hline 3 & $\mathrm{BMI}$ & $.2668 \quad(.0213)$ & $28.4 \mathrm{~g} / \mathrm{BMI}$ & $\mathrm{BMI}$ & $.2912(.0535)$ & $34.6 \mathrm{~g} / \mathrm{BMI}$ \\
\hline 4 & $\mathrm{SEX}^{\mathrm{c})}$ & $.2873(.0205)$ & $-117.7 \mathrm{~g}$ & SEX & $.3094(.0182)$ & $-114.6 \mathrm{~g}$ \\
\hline 5 & MHT & $.2960 \quad(.0087)$ & $8.4 \mathrm{~g} / \mathrm{cm}$ & MHT & $.3150 \quad(.0056)$ & $8.3 \mathrm{~g} / \mathrm{cm}$ \\
\hline 6 & PSA & $.2999 \quad(.0039)$ & $-80.1 \mathrm{~g} /$ time & AGE & $.3211(.0061)$ & $7.0 \mathrm{~g} /$ year \\
\hline 7 & & & & PMT & $.3238 \quad(.0027)$ & $-93.3 \mathrm{~g} /$ time \\
\hline 8 & & & & PAR & $.3254(.0016)$ & $22.7 \mathrm{~g} /$ time \\
\hline
\end{tabular}

a) Probability of F-to-enter $=0.05$; Probability of F-to-remove $=0.10$ b) VAR: Variables; Abbreviations of variables are the same as those in Table 1 c) male $=0$, female $=1 \quad(\quad)$ Increment of $R^{2}$ with each factor

dichotomous category of parity (primiparae, multiparae), in order to examine the magnitude of the parity effect and parity-age interaction. Within primiparae, maternal age was not included in the equation. On the other hand, within multiparae, effects of age and parity were likely to be smaller than in all cases together, as shown in Table 2. These findings may suggest that there is an interaction between maternal age and parity in regard to effects on birth weight. The correlation coefficient between maternal age and parity was 0.493 . It has been suggested that the effect of parity becomes negative with grand multiparity ${ }^{29)}$. Our results also show that the effect of parity is smaller among multiparae than between primiparae and multiparae, which suggest that the effect of parity on birth weight contains a squared term in their relationship and that some part of the age effect on birth weight could be exerted through the squared term of parity. Similarly, the correlation coefficient between maternal age and BMI was rather high with 0.223 , which also indicated that there might exist an age-BMI interaction effect on birth weight. In this case we need to include the orthogonal polynomial of parity and BMI, and an interaction term between them in the regression model.

Table 5 shows the result of multiple regression analysis in which (parity-mean of parity) ${ }^{2}$, (BMImean of $\mathrm{BMI})^{2}$, age $\times$ parity, age $\times \mathrm{BMI}$ and parity $\times \mathrm{BMI}$ were included in the analysis as independent 
Table 5 Factors associated with birth weight analyzed by a multiple regression model when including the squared term of parity and BMI, and interaction terms among parity, age and BMI as independent variables $\left(\mathrm{N}=3000\right.$, stepwise method $\left.{ }^{\mathrm{a}}\right)$.

\begin{tabular}{|c|c|c|c|c|c|}
\hline Step & $\mathrm{VAR}^{\mathrm{b})}$ & Cumulati & e square $\mathrm{R}$ & Beta $^{\text {c) }}$ & Regression coefficient \\
\hline 1 & GPR & .1809 & & .4257 & $109.2 \mathrm{~g} /$ week \\
\hline 2 & $A-B^{d)}$ & .2222 & $(.0413)$ & .2037 & 0.2 \\
\hline 3 & GWG & .2717 & $(.0495)$ & .2295 & $25.8 \mathrm{~g} / \mathrm{Kg}$ \\
\hline 4 & $\operatorname{SEX}^{\mathrm{e})}$ & .2893 & $(.0176)$ & -.1344 & -116.9 \\
\hline 5 & MHT & .2990 & $(.0097)$ & .1020 & $8.6 \mathrm{~g} / \mathrm{cm}$ \\
\hline 6 & PAR & .3082 & $(.0092)$ & .1098 & $82.3 \mathrm{~g} / \mathrm{birth}$ \\
\hline 7 & BMI & .3191 & $(.0109)$ & .1537 & $30.8 \mathrm{~g} / \mathrm{BMI}$ \\
\hline 8 & $\mathrm{SPA}^{\mathrm{f}}$ & .3243 & $(.0052)$ & -.0914 & $-20.2 \mathrm{~g} / \mathrm{birth}^{2}$ \\
\hline 9 & $\mathrm{SBM}^{\mathrm{g})}$ & .3268 & $(.0025)$ & -.0594 & $-1.9 \mathrm{~g} / \mathrm{BMI}^{2}$ \\
\hline 10 & PMT & .3287 & $(.0019)$ & -.0479 & $-95.3 \mathrm{~g} / \mathrm{birth}$ \\
\hline
\end{tabular}

a) Probability of F-to-enter $=0.05$; Probability of F-to-remove $=0.10$ b) Abbreviations of variables are the same as those in Table 1 c) Standardized regression coefficient d) term of the age-BMI interaction e) male $=0$, female=1;f) Square of parity; (parity-mean of parity) ${ }^{2}$ g) Square of BMI: (BMI-mean of BMI) ${ }^{2}$ ( ) Increment of $\mathrm{R}^{2}$ with each factor

variables. In this analysis we used the squared term of each variable minus the mean value both for parity and BMI, in order to avoid the undesirable effect on the regression equation caused by strong correlation between the usual linear term and the squared term. The squared term of parity and BMI with a negative effect, and the age-BMI interaction term with a positive effect were included in the equation, while neither age-parity interaction nor parity-BMI interaction were included. Furthermore, in this analysis the maternal age was not included in the equation, indicating that maternal age did not appear to have an independent effect on pregnancy outcome.

Table 6 shows the result of the multiple regression analysis of gestational weeks. Among 8 factors, four factors were included in the equation with significant effects. The results suggested that infant sex, (in the case of females), maternal height, and BMI have positive effects on gestational weeks, and that prior prematurity has a negative effect. Birth weight is governed by two major processes, gestational period and intrauterine growth and, as a result, low birth weight in infants can be caused by either a short gestational period or intrauterine growth retardation. Therefore, the results of this analysis indicate that the effects of these 4 factors on birth weight might be partially exerted through the gestational period.

Table 6 Factors associated with gestational age analyzed by a multiple regression model $(N=3000$, stepwise method $^{\mathrm{a})}$ ).

\begin{tabular}{cccr}
\hline Step & VAR $^{\text {b) }}$ & $\begin{array}{c}\text { Cumulative } \\
\text { squared R }\end{array}$ & Beta $^{\text {c) }}$ \\
\hline 1 & SEX & .0102 & .1010 \\
2 & PMT & $.0149(.0047)$ & -.0688 \\
3 & MHT & $.0169(.0020)$ & .0444 \\
4 & BMI & $.0182(.0013)$ & .0368 \\
\hline
\end{tabular}

a) Probability of F-to-enter $=0.05$; Probability of F-to-remove $=0.10$ b) Abbreviations of variables are the same as those in Table 1 c) Standardized regression coefficient d) male $=0$, female $=1$ ( ) Increment of $\mathrm{R}^{2}$ with each factor 
Table 7 shows MBW of singleton infants with 40 gestational weeks stratified by maternal height, BMI, parity, sex, and gestational weight gain. Category borders were determined to fall near the mean value of each variable. Because of limiting the gestational period for 40 weeks, our results can be interpreted to indicate effects on intrauterine growth. These results indicate that the body mass index, gestational weight gain, parity, and maternal height have positive effects on intrauterine growth and that male infants have better intrauterine growth than females. Some pairs according to parity, sex, gestational weight gain, and BMI showed statistically significant differences.

Table 7 Mean birth weight of singleton babies with 40 gestational weeks stratified by maternal height, Body Mass Index, parity, sex, and gestational weight gain.

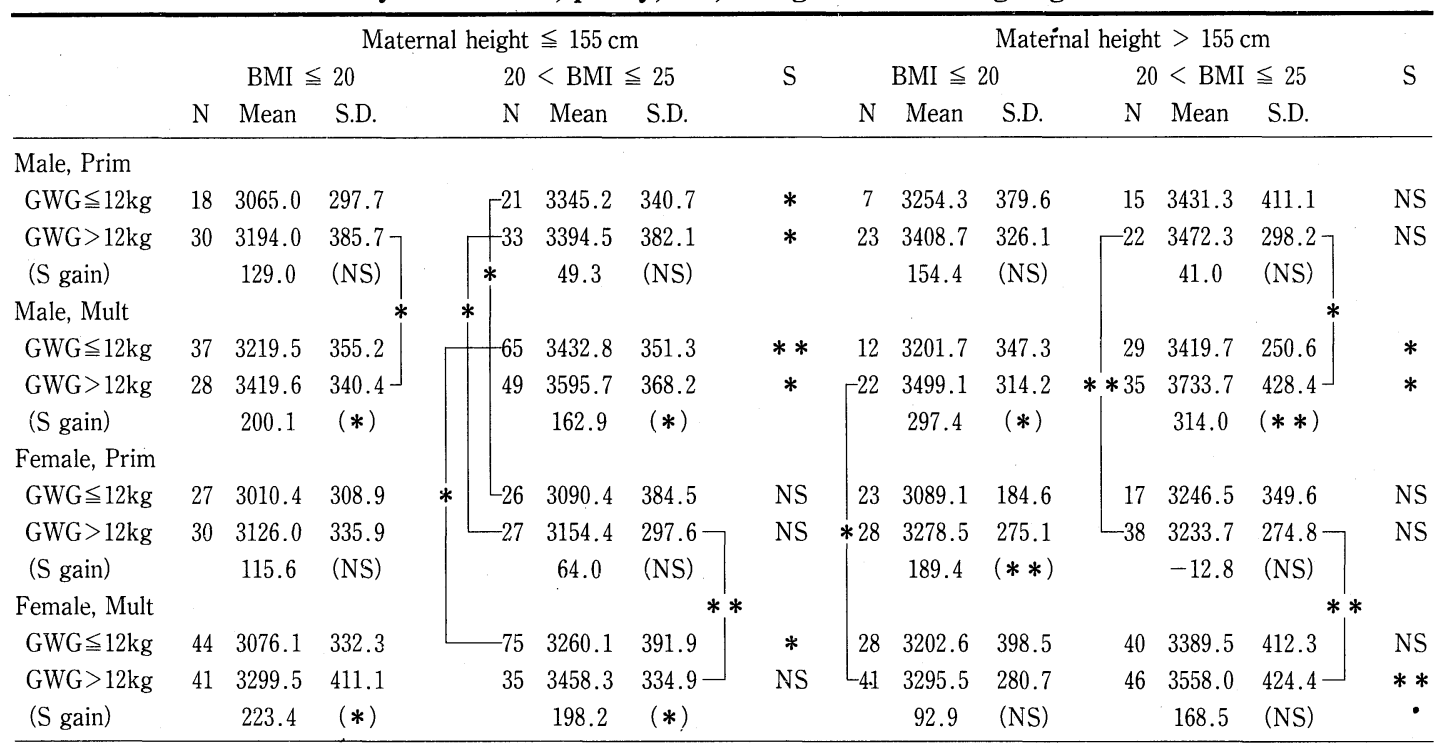

$\mathrm{S}$ : Comparison between two groups according to Body Mass Index ( $\mathrm{t}$-test) $\mathrm{S}$ gain : Comparison between two groups according to weight gain during pregnancy (t-test) $* *: p<0.01 ; *: p<0.05$; NS : not significant

\section{DISCUSSION}

The birth weight distribution of this facility was better than that of both Japan as a whole and Okinawa. It may be partly because this facility is located downtown in the city of Naha and most of the patients belong to the middle or upper social classes ${ }^{23,24}$, and partly because in this facility the percentage of multiparae was higher than in other facilities. On the other hand, this higher MBW might suggest the possibility that the birth-weight distribution of Okinawa can be improved to this level in the future by some appropriate interventions.

By the regression analysis of birth weight we detected 9 significant factors in birth weight. They are as follows: gestational weeks, pre-pregnancy BMI, gestational weight gain, parity, infant sex, maternal height, maternal age, prior prematurity, and prior spontaneous abortion, in this order. Among them, gestational weeks had the most important effect with a squared $\mathrm{R}$ of 0.18 . The relationship between birth weight and gestational weeks is more relevant for shorter gestational periods. Furthermore, we were able to account for higher proportions of the variance in birth weight in shorter gestational periods. These results suggest that it is necessary for researchers to take into account the nonlinear relation between gestational weeks and birth weight in assessing factors that influence birth weight. Showstack et al. ${ }^{9)}$ also suggested the same effect of this nonlinearity on birth weight.

Our results also suggest that 4 factors, the sex of infants, maternal BMI, gestational weight gain and 
prior prematurity, have significant effects on the number of gestational weeks, which might mean that effects of these factors on birth weight are partially exerted through the length of gestation.

Among them, the effect of infant sex is of interest. Table 6 shows that female infants had slightly but significantly longer gestational periods than males. On the other hand, Table 7 shows that male infants had better intrauterine growth than females. The mechanism of labor is multifactorial, including anatomical and hormonal factors ${ }^{30}$. It has been suggested that overstretching of the uterus may play some part in causing the onset of labor. If this is true, there is a possibility that the female fetus remains longer in the uterus than the male because of its relatively slow intrauterine growth. Hormonal differences between males and females may cause the difference in gestational periods. Kramer ${ }^{31}$, however, suggested that infant sex has no effect on gestational age. Further studies, including experimental study, are needed to identify the effect of the sexual difference on gestational age.

It is well established that maternal pre-pregnancy nutritional status is a significant factor associated with birth weight ${ }^{8,10 \sim 11,13 \sim 18)}$. Both pre-pregnancy weight and pre-pregnancy BMI can be used to express the nutritional condition. In this study we used the BMI (the Quetelet index) in order to control the confounding effect of maternal height. Our results suggest that pre-pregnancy nutritional status can have a significantly positive effect both on intrauterine growth and gestational age. The result for intrauterine growth agrees with previous reports, but the effect on gestational age is uncertain ${ }^{31}$. The squared term of BMI with a negative effect shown in Table 5, however, indicates that the effect of BMI on birth weight might be negative with highly obese mothers.

Gestational weight gain was detected as another nutritional factor with a significantly positive effect. This factor corresponds to caloric intake during pregnancy, which provides stores of energy for growth of the fetus and lactation. According to Hytten and Leitch ${ }^{32)} 1 \mathrm{~kg}$ of gestational weight gain is equal to $6,000 \mathrm{Kcal}$ of caloric intake during gestation. On the basis of this conclusion a number of food supplementation programs have been implemented ${ }^{17 \sim 19)}$. The WHO Expert Committee reported that food supplementation is most effective during the last trimester of pregnancy ${ }^{33}$. This report is based on the increased nutritional requirement of the fetus during the last month of gestation, since the rate of fetal growth increases, on average, up to the 38 th week $^{34)}$. However, Lechtig et al. ${ }^{15)}$ have suggested that the total amount of calories during pregnancy might be the main nutritional factor because gestational weight gain starts earlier than fetal growth and reveals a linear pattern during the last two trimesters. In other words, an adequate caloric store in the early stage of pregnancy may provide sufficient energy for subsequent fetal growth. From the public health point of view, this fact is important, because it means that the earlier in pregnancy a woman starts supplementation, the more likely it is that she will get enough calories to produce a better outcome.

Another important consideration is the possibility that the pre-pregnancy nutritional condition could limit the effect of supplementation. Previous reports suggest that the effect of nutrition during pregnancy is significant if the mother is not well nourished prior to pregnancy ${ }^{15,19)}$, but not significant among mothers who are well nourished prior to pregnancy ${ }^{15,18}$. Table 7 shows that the differences of MBW between two groups according to gestational weight gain are likely to be larger among the smaller-BMI group than the larger-BMI group. We carried out multiple regression analyses within two BMI groups, which were $\mathrm{BMI} \leq 20$, and $20<\mathrm{BMI} \leq 25$. According to this analysis, the increment of squared $\mathrm{R}\left(\mathrm{d}-\mathrm{R}^{2}\right)$ with gestational weight gain and regression coefficient $(B)$ of this factor were almost the same between the two groups $\left(\mathrm{BMI} \leq 20: \mathrm{d}-\mathrm{R}^{2}=0.0526, \mathrm{~B}=27.8 ; 20<\mathrm{BMI} \leq 25: \mathrm{d}-\mathrm{R}^{2}=0.0584, \mathrm{~B}=27.5\right)$. Furthermore, we carried out multiple regression analysis after changing the category of $\mathrm{BMI}$, that is, $\mathrm{BMI} \leq 19$, and $19<\mathrm{BMI} \leq 25$. In this analysis we found a larger effect of gestational weight gain within the smaller-BMI group than within the larger-BMI group $\left(B M I \leq 19: d-R^{2}=0.0718, B=32.7 ; 19<B M I \leq 25: d-R^{2}=0.0483\right.$, $B=26.7$ ). These results suggest that the effect of gestational weight gain in larger among smaller-BMI groups. However, further studies are needed on this effect, including the problem of categorization of the factor.

A slightly significant effect on birth weight was observed with maternal age. However, interpretation of its effect should be done with care because parity, BMI and the squared term of both parity and 
BMI were associated with maternal age, which might mean that the observed effect of maternal age is confounded with parity and BMI. Previous reports disagree about its effect ${ }^{16,19,31)}$.

We found a negative effect of prior spontaneous abortion on birth weight. The results of previous studies disagree about the effect of prior spontaneous abortion ${ }^{31,35,36)}$. It is necessary to clarify its effect, including analysis of the effect of post abortion dilatation and curettage.

There is general agreement that pregnancy outcomes are more favorable for multiparae than primiparae, as shown in our results. The squared term of parity with a negative effect shown in Table 5 , however, indicates that grand multiparity might have a negative effect on birth weight. Previous reports disagree about the effect of grand multiparity ${ }^{29,31}$.

In this study we could not get information about the smoking habits of mothers. Available findings have concluded that smoking during the pregnancy period is an important factor associated with birth weight with a negative effect ${ }^{10,11,16,20,31)}$. Recently the number of young women who have a smoking habit is increasing in Japan ${ }^{37}$. As we mentioned above, the MBW of Japan has been decreasing since 1976. The recent increase of women with a smoking habit may play some part in this secular change. Of course there are many other possible factors that can have causal effects on this change such as the change of maternal constitution and dietary habits, the increased number of working women, effects of pollutants and chemicals, and so on.

Recently, it has been reported that adequate prenatal care has a substantial association with higher birth weight ${ }^{8,9}$. But it has not been clarified which aspects of prenatal care may lead to improved birth weight. Adequate prenatal care may involve preventable effects on harmful factors, such as smoking habit, complications of pregnancy and undesirable dietary habits. To create a more effective program of prenatal care, it is necessary for researchers to clarify the relationship between prenatal care and several prenatal factors.

Furthermore, from the public health point of view, we should advance to the next stage, where we can use the birth weight distribution as a tool of community evaluation. There are a number of questions that must be asked about its availability and usefulness in a practical health program, among them:

1) Can the birth weight distribution be measured in a given community, especially in rural developing areas?

2) Does a plan which aims to improve the birth-weight distribution lead to total health promotion in a given community?

3) If that is true, what kind of health-promoting services should be adapted?

4) Is such a plan resonable from the cost-benefit point of view?

Although some problems remain to be discussed, it is clear that the measurement and evaluation of birth-weight distribution will provide an ideal follow-up system and lead to the evolution of a communitywide learning process. This is important, especially for the primary health care system in rural developing countries, because during this process community members may come to realize that the LBW baby has a great risk of infant mortality and that there are many preventable factors that result in LBW. This process will lead to self-awareness and learning among community members, which are necessary for the basic concept of primary health care ${ }^{38)}$ and indispensible for future development.

Acknowledgments : This work was accomplished under the guidance of Prof. Kahyo H. (Department of Human Ecology, UOEH). The author wish to thank him for his helpful advice and criticism. The author is grateful to Associated Prof. Doi T. (Department of Human Ecology, UOEH) for his advice about statistical analysis; Dr. Akamine M. (Akamine Obstetric and Gynecological Clinic, Naha) for his help to collect data.

\section{REFERENCES}

1) SAREC/WHO Workshop. : Birth-weight distribution - an indicator of social development, SAREC REPORT No. R: 2 (1978).

2) Meredith, H.V.: Body weight at birth of viable human infants, Hum. Biol., 42, 217-264 (1970).

3) Gruenwald, P. : Influence of environmental factors on foetal growth in man, Lancet, 1, 1026-1029 (1967).

4) Kahyo, H. : Birth weight as a community health indicator, J. Health and Welfare Statistics, 22, 12-27 (1975). 
5) McCormick, M.C. : The contribution of low birth weight to infant mortality and childhood morbidity, N. Eng. J. Med., 312, 82-90 (1985).

6) Semenciw, R.M., Morrison, H.I., Lindsay, J., et al. : Risk factors for postneonatal mortality : Results from a record linkage study, Int. J. Epidemiol., 15, 369-372 (1986).

7) Thomson, A.H., Billewicz, W.Z. and Hytten, F.E. : The assessment of fetal growth, J. Obstet. Gynaec. Brit. Cwlth., 75, 903-916 (1968).

8) Horon, I.L., Strobino, D.M. and MacDonald, H.M. : Birth weights among infants born to adolescent and young adult women, Am. J. Obstet. Gynecol., 146, 444-449 (1983).

9) Showstack, J.A., Budetti, P.P. and Minkler, D. : Factors associated with birthweight: An exploration of the roles of prenatal care and length of gestation, Am. J. Public Health, 74, 1003-1008 (1984).

10) Klebanoff, M.A., Graubard, B.I., Kessel, S.S., et al. : Low birth weight across generations, JAMA, 252, 2423 -2427 (1984).

11) Yudkin, P.L., Harlap., S. and Baras, M.: High birthweight in an ethnic group of low socioeconomic status, Br. J. Obstet. Gynecol., 90, 291-296 (1983).

12) Cawley, R.H., McKeown, T. and Record, R.G. : Parental stature and birth weight, Am. J. Hum. Genet., 6, 448 -456 (1954).

13) Niswander. K. and Jackson, E.C.: Physical characteristics of the gravida and their association with birth weight and perinatal death, Am. J. Obstet. Gynecol., 119, 306-313 (1974).

14) Pritchard, C.W., Sutherland, H.W. and Carr-Hill, R.A.: Birthweight and paternal height, Br. J. Obstet. Gynecol., 90, 156-161 (1983).

15) Lechtig, A., Yarbrough, C., Delgado, H., et al. : Influence of maternal nutrition on birth weight, Am. J. Clin. Nutr., 28, 1223-1233 (1975).

16) Papoz, L., Eschwege, E., Pequignot, G.; et al.: Maternal smoking and birth weight in relation to dietary habits, Am. J. Obstet. Gynecol., 142, 870-876 (1982).

17) Lechtig, A., Habicht, J.P., Delgado, H., et al. : Effect of food supplementation during pregnancy on Birthweight, Pediatrics, 56, 508-520 (1975).

18) McDonald, E.C., Pollitt, E., Mueller, W., et al.: The Bacon Chow study : maternal nutritional supplementation and birth weight of offspring, Am. J. Clin. Nutr., 34, 2133-2144 (1981).

19) Rush, D., Stein, $Z$. and Susser, M. : A randomized controlled trial of prenatal nutritional supplementation in New York City, Pediatrics, 65, 683-697 (1980).

20) Kline, J., Stein, Z. and Hutzler, M. : Cigarettes, alcohol and marijuana : Associations with birthweight, Int. J. Epidemiol., 16, 44-51 (1987).

21) Kahyo, H., Yamashiro, R. and Higa, K. : Studies on the birth weight in the Ryukyu Islands (1), JJPH, 22, 647 -653 (1975).

22) Doi, T.: Mean birth weight as a community health indicator and its secular changes, JJPH, 30, 511-526 (1983).

- 23) Kahyo, H. and Yamashiro, R.: Changes in the mean birth weight by gestational week at an obstetric service in Naha during the past twenty years, Jpn. J. Hyg., 31, 614-633 (1976).

24) Kahyo, H. and Doi, T.: Differences in the mean birth weight by gestational age in weeks between A. Private clinic and O. public hospital in Naha, J. UOEH., 1, 137-145 (1979).

25) National Institutes of Health Consensus Development Conference Statement. Ann. Intern. Med., 103, 10731077 (1985).

26) SPSSX User's guide, 2nd ed. SPSS, Inc (1983).

27) Vital Statistics Japan (1978-87). Health and Welfare Statistics and Information Department, Minister's Secretariat, Ministry of Health and Welfare.

28) Gruenwald, P. : Growth of the human fetus. I. Normal growth and its variation, Am. J. Obstet. Gynecol., 94, 1112 (1966).

29) Fabia, J.: Regression multiple du poids de naissance utilisant dix variables "predictives", Can. J. Public Health, 64, 548-551 (1973).

30) Danforth, D.N. ed.: Obstetrics and Gynecology, 4th ed. Chap 29, p. 576-621, East Washington Square, Philadelphia, Pennsylvania. Harper \& Row, Inc. (1982).

31) Kramer, M.S. : Determinants of low birth weight: methodological assessment and meta-analysis, Bull. WHO., 65, 663-737 (1987).

32) Hytten, F.E. and Leitch, I. : The physiology of human pregnancy, 2nd ed. Oxford, Blackwell (1971).

33) WHO: Technical report series No. 302, Nutrition in pregnancy and lactation (1965). 
34) Payne, P.R. and Wheeler, E.F.: Comparative nutrition in pregnancy and lactation, Proc. Nutr. Soc., 27, 129 -138 (1968).

35) Linn, S., Schoenbaum, S.C., Monson, R.R., et al.: The association of marijuana use with outcome of pregnancy, Am. J. Public Health, 73, 1161-1164 (1983).

36) Linn, S., Schoenbaum, S.C., Monson, R.R., et al.: No association between coffee consumption and adverse outcomes of pregnancy, N. Engl. J. Med., 306, 141-145 (1982).

37) Takemura, T.: Smoking and health for women, JJMA, 98, 1075-1078. (1987).

38) WHO : Primary Health Care, Report of the International Conference on Primary Health Care, Alma-Ata, U. S.S.R., WHO, (1978).

\title{
線形重回帰モデルによる出生時体重に関連する要因の分析
}

\author{
産業医科大学医学部公衆衛生学教室
}

松田晋 哉

那覇市内の某産婦人科医院で1978年から1987年までの10年間に出生した単産出生児 3,000 例の分婏記録を資料として, 出生時体重と出産に関連する10の因子との関係について重回帰分析を行った。

10の要因のうち, 人工流産歴を除く 9 つの因子（在胎週, 妊娠前の母親の肥満度, 母親の姡娠中の体重増加量, 出産 歷, 児の性, 母親の身長, 母親の年齢, 早産歷, 自然流産歴)が, 出生児体重に有意に関連するものとして検出された。

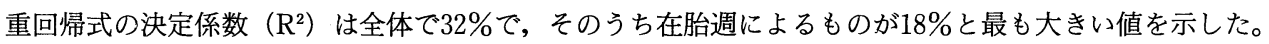

次に, 在胎週を 3 つの異なる期間に限定して (41週, 40 週, 39 週 $\geqq)$, 重回帰分析を行ったところ, 在胎週が短い ほど全体の $\mathrm{R}^{2}$ および在胎週による $\mathrm{R}^{2}$ は増加した。この現象は，在胎週 38 週前後から胎児の体重増加度が頭打ちになる という，在胎期間と胎児体重の非直線的な関係によるものと考えられた。

出生児体重を規定するものは，大きく二つに分けて子宮内発育度と在胎期間であると考えられる。そこで，在胎週を 目的変数として重回帰分析を行った。その結果, 児の性, 母親の身長, 母親の妊娠前の肥満度, および早産歴の 4 つの 因子が有意に関係するものとして検出された。このことから, これら 4 因子の出生児体重に対する影響の一部分は, 在 胎期間への効果を介していることが示唆された。

Key words: Birth weight, Gestational week, Multiple regression analysis 出生時体重, 在胎週, 重回帰分析 